\title{
Immunohistochemical Analysis of Alveolar Bone Preserved with Autologous Teeth Graft. Osteopontin Expression and its Regulatory Functions in Preserved Alveolar Ridge
}

\author{
Análisis Inmunohistoquímico de Hueso Alveolar Preservado con Injerto Dental Autólogo. \\ Expresión de Osteopontina y sus Funciones Regulatorias en el Reborde Alveolar Preservado
}

\author{
Moreno-Villagrana Ana Patricia'; Gutiérrez-Valdés Dulce Haydeé \& Flores-Luna María Guadalupe ${ }^{3}$
}

\begin{abstract}
MORENO-VILLAGRANA A. P.; GUTIÉRREZ-VALDÉS, D. H. \& FLORES-LUNA, M. G. Immunohistochemical analysis of alveolar bone preserved with autologous teeth graft. Osteopontin expression and its regulatory functions in preserved alveolar ridge. Int. J. Odontostomat., 15(3):616-625, 2021.
\end{abstract}

ABSTRACT: The present study investigated the healing response of 12 fresh post-extraction alveolous grafted with particulate autologous teeth to achieve preservation of the post-extraction alveolar ridge. The objective is to elucidate the osteoconductive and osteoinductive properties of the autologous dental graft used as a bone substitute in the alveolar ridge preservation technique. Five patients were included, with at least one hopeless tooth and in need of extraction and preservation of the ridge, to receive in the same place a dental implant in prosthetic replacement. In the first surgical stage, dental extractions and preservation of the alveolar ridge were performed, using the teeth extracted and processed with an automatic system as bone substitutes. In the second surgical stage, an incisional bone biopsy was performed in each grafted site, the bone beds were recapitulated in a drilling protocol that allowed the placement of the dental implant, and the harvested bone specimens were prepared for analysis. The histological results of the bone biopsies in all cases showed remnant particles of the dental graft, made up of dentin, partially resorbed, with irregular superficial edges and in close contact with newly formed bone in transition to mature lamellar bone, in which well differentiated osteocytes were observed. The immunohistochemical results showed a moderate positive expression of osteopontin at the edges of the integrated teeth particles, inside the peritubular dentin space and at the osteodental contact interfaces. In conclusion, the evidence from the study shows that the autologous dental graft is a biocompatible bone substitute, that provides an osteoconductive scaffold that promotes bone cell adhesion and migration for local osteogenesis and that it is associated with moderate in situ expression of osteopontin, which showed a high affinity with mineralized dental tissue, suggesting osteoinductive properties in situ.

KEY WORDS: teeth graft, tooth graft, alveolar bone grafting, alveolar ridge preservation, osteopontin.

\section{INTRODUCTION}

Tooth extraction is one of the most widely performed procedures in dentistry and it has been documented that the healing of an extraction socket involves a bone tissue turnover (Horowitz et al., 2012), which induces significant dimensional changes that inevitably leads to atrophy of the alveolar ridge (Atwood, 1971). Several human studies have shown that a marked reduction in alveolar ridge dimensions takes place during the first 3 months after tooth extraction. Loss of the bundle bone results in significant horizontal bone loss and vertical ridge contraction of the facial plate (Araújo \& Lindhe, 2005). This process of bone remodeling is progressive and can continue at a slower rate for a life time (Pietrokovski \& Massler, 1967), so that the shape of the jawbone appears to return to the shape that was present prior to the development of

\footnotetext{
${ }^{1}$ Professor at Universidad Tecnológica de México (UNITEC), Faculty of Dentistry, Postgraduate Division, Periodontics Department. ORCID: 0000-0001-5919-5912.

${ }^{2}$ Academic director and professor at Universidad Tecnológica de México (UNITEC), Faculty of Dentistry. ORCID: 0000-0002-8446-5109.

${ }^{3}$ Academic director and professor at Universidad Tecnológica de México (UNITEC), Faculty of Dentistry, Posgraduate Division. ORCID: 0000-0002-1949-4130.
}

Received:2021-01-24 Accepted: 2021-03-20 
the alveolar process during tooth eruption. In the absence of teeth, the lack of a biomechanical functional stimulus on the bone walls and, the need for tissue adjustment to meet genetically determined demands regarding ridge geometry, may explain the post extraction alveolar ridge modifications (Araújo \& Lindhe; Araújo et al., 2015).

Many surgical techniques have been developed to prevent or reconstruct the post extraction bone resorption and to maintain the architecture of the residual alveolar ridge. The Alveolar Socket Preservation (ASP) or Alveolar Ridge Preservation (ARP) procedures use bone substitutes as grafting materials for reducing dimensional changes of the edentulous alveolar ridge (Willenbacher et al., 2016), since they mimic the organic and mechanical healing microenvironment needed for bone formation (Andersson et al., 1984; Al-Asfour et al., 2014). The efficacy of this technics that assist the post extraction bone healing, using different grafting biomaterials, is evaluated by means of histological analysis of the grafted sites, which describe the alveolar bone survival through osseous volume and achieved bone quality, the results have shown that bone substitutes influence bone healing in different ways (Chan et al., 2013) and no recommendation can be made referring to any of the ASPIARP techniques, because the evidence on graft materials needs to be further assessed in welldocumented research (Willenbacher et al.).

Since 1967, the osteoinductive potential of dentin was first described (Yeomans \& Urist, 1967) and later in 1970, it was showed that mineralized autologous tooth grafts lead to a dentoalveolar ankylosis, a process that is often seen after reimplantation of avulsed teeth and in retained dental roots in alveolar bone (Pindborg, 1970; Buser et al., 1990). The Dentoalveolar ankylosis is the fusion of the alveolar bone with cementum or dentin, followed by an osseous creeping substitution (Huggins et al., 1970), the direct connection between alveolar bone and mineralized tooth tissues, has led to several studies that have documented that autogenous human teeth can be favorable bone substitutes for periodontal defects and extraction socket graft (Upadhyay et al., 2019; Kim et al., 2010; Kim et al., 2014a; Kim et al., 2014b), because dental hard tissues and bone share similar mineral composition and proteomic profiles (Salmon et al., 2017); for example, they both consist of $10 \%$ body fluid, $70 \%$ minerals (mainly hydroxyapatite) and $20 \%$ organic materials, including type I and type III Collagen, Bone Morphogenetic Proteins (BMPs), type I and type II
Insulin-Like Growth Factor (IGF - I and II), Transforming Growth Factor $\beta$ (TGF- $\beta$ ), Matrix metalloproteinase-20 (MMP20) and some others extracellular matrix proteins (Al-Asfour, 2014; Salmon et al.; Kadkhodazadeh et al., 2015). Nowadays, the preservation of the alveolus for jawbone health with autologous particulate teeth graft regarding its osteoinductive properties are not yet fully understood and need to be systematically investigated.

Osteopontin (OPN) is a nonstructural matricellular protein, member of the SIBLING (Small Integrin-Binding Llgand N-linkend Glycoprotein) family, which distribution and organization varies from tissue to tissue and from stage to stage. One of the multiple functions of OPN is to act as a bridge between the surfaces of different cells and their extracellular matrix, as it can bind to multiple ligands, including, on one side, cell membrane integrins and, on the other side, extracellular matrix proteins, as fibronectin and collagens. During histogenesis and tissue remodeling, the OPN bridging function enables cell movement over extracellular matrix proteins, protecting cells from early death by maintaining their adherence to the protein substrate of the matrix, this cellular anchoring process is essential for angiogenesis and cell repopulation processes (Senger et al., 1996). In particular, OPN serve as a regulation factor of bone healing and turnover, since it enhances or inhibits calcification depending upon its phosphorylation, so that OPN modulates apposition and resorption of apatite minerals in vivo (Giachelli et al., 2005).

The aims of the present study is to elucidate the osteoconductive and osteoinductive properties of the autologous teeth particle graft used as bone substitute in ASPIARP techniques, by means of the histological analysis of teeth particles integration and bone histogenesis promoted at grafted alveolar sockets, as well as the immunohistochemical identification of osteopontin (OPN) expression in healed alveolar bone.

\section{MATERIAL AND METHOD}

This study was conducted from February to December 2017 at the Postgraduate Division of the Faculty of Dentistry of Universidad Tecnológica de México (UNITEC), after obtaining approval from the bioethics committee (registration code UNITEC 17-213) as a quasi-experimental research. The present work is considered of risk greater than the minimum according to article 17 of the General Regulation of Health in the Matter of Research for Health. 
Patients and entry criteria. The inclusion criteria were as follow: (1) patient in need of single dental extraction of non-root filled hopeless teeth and programmed for delayed implant placement at the extraction site, (2) age $\geq 20$ and $\leq 60$ years, (3) patients ASA Class I and II, who were healthy or who had controlled systemic disease(s). Patients who met any of the following exclusion criteria were eliminated: (1) patients with significant comorbidities (such as recent heart attack, coagulation and psychiatric disorders), (2) smokers, (3) alcohol and/or drug consumers, (4) patients who had undergone chemo or radio therapy, (5) patients with untreated periodontitis and/or parafunction habits, (6) patients who had received bone graft on the treated site, and (7) patients with acute odontogenic infection, periapical lesion or non-contained alveolar bone defect with less than $4 \mathrm{~mm}$ of vertical dimension.

Among the patients who visited the Faculty of Dentistry, a total of 5 patients with 12 hopeless teeth, in need of delayed implant placement, satisfied the inclusion criteria, all were explained about the procedure of socket graft using their own crushed teeth, all agreed the informed consent and extracted their hopeless teeth. Demographic information of the patients and the location of extracted teeth is shown in Table I.

Table I. Demographic and clinical data of participants $(n=5)$.

\begin{tabular}{lc}
\hline Participants & \\
\hline Sex (Male:Female) & $(3: 2)$ \\
Age (year mean \pm sd) & $45 \pm 7$ \\
Ethnic group & Latin American \\
ASA dassification $(\mathrm{I}:$ II) & $(3: 2)$ \\
Graft sites & \\
Number of bone grafted sites & 12 \\
Bone defect area & \\
Maxilla, anterior & 3 \\
Maxilla, premolar & 3 \\
Maxilla, molar & 2 \\
Mandible, anterior & 1 \\
Mandible, premolar & 0 \\
Mandible, molar & 3 \\
\hline
\end{tabular}

Surgical procedure and preparation of the autogenous teeth graft. After a primary periodontal hygienic therapy, the teeth extractions were performed by 4 undergraduated periodontist, under local anesthesia; complete curettage and wound irrigation were performed at fresh alveolar sockets. Extracted teeth were transoperatively scrapped with a No. 8 carbide bur to remove off any remaining soft tissues, restorative materials, decay and softened hard tissues, cleaned with distilled water and disinfected for the first time in $75 \%$ alcohol for further processing. Then, the teeth were crushed into particles of diameter between 300 and $800 \mu \mathrm{m}$, with an automatic clinical grinder, at a $700 \mathrm{rpm}$ speed. The teeth particles were washed, defatted, disinfected for the second time and partially dried for clinical use, as protocol recommendations (KometaBio. New Jersey, USA), Figure 1. Alveolar fresh sockets were debrided, rinsed with abundant physiologic solution and grafted with autogenous particle teeth and wound closure was achieved with a collagen nonfriable sponge (Zimmer; Indiana, USA) and 5-0 PGA suture mattress (Ethicon; Ohio, USA), Figure 2. Follow-up was provided to each patient, performing a review 7 days after teeth extraction and ARP procedures, sutures were removed after 14 days and monthly reviews were performed until the 7th postoperative month was achieved, due to Faculty calendar.
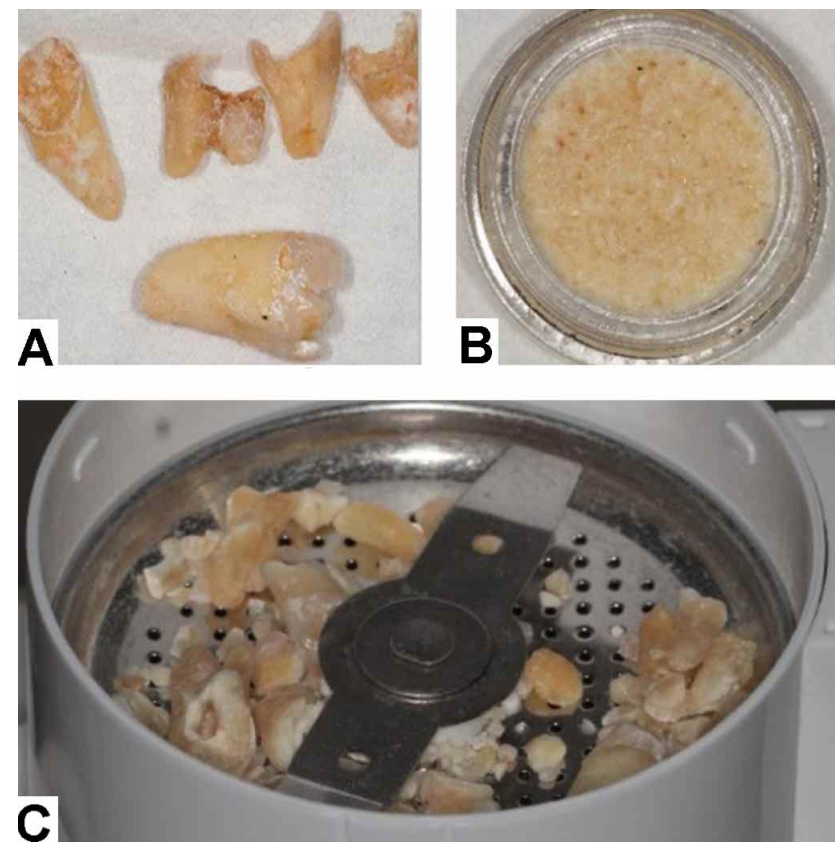

Fig. 1. Extracted and cleaned teeth (A), placed inside the automatic grinder (B) and final aspect of the particulate teeth, prepared for alveolar socket grafting (C).

On the 8th month, cone beam computerized tomographic (CBCT) studies of the maxillomandibular complex of the 5 patients enrolled in the study were obtained, their results allowed the reassessment of the grafted anatomical sites in the alveolar ridge and the presurgical planning. The dental implants surgeries were performed after a postoperative healing period of 8 months and with the patient's consent, 12 incisional bone biopsies were harvested, from the previously 

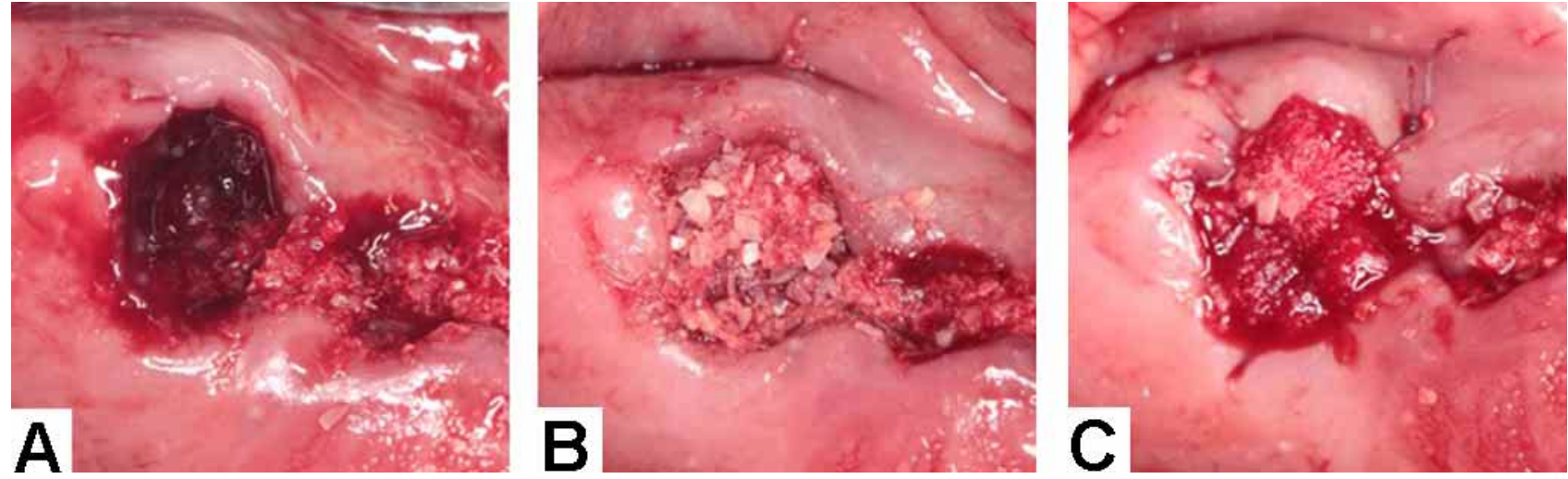

Fig. 2. Alveolar fresh sockets (A), grafted with autogenous teeth graft $(B)$ and wound closure with a collagen nonfriable sponge and 5-0 PGA suture mattress (C).

planned implant sites that were grafted, using a standard trephine bur (inner diameter $2 \mathrm{~mm}$ and $12 \mathrm{~mm}$ length. Dental Implant Technologies; Arizona, USA). Biopsies were performed at the time of the surgical placement of each dental implant; in each case, the remaining bone bed from the bone biopsy was part of the receptor bed milled for the dental implant. (Fig. 3). The obtained bone cores samples were immersed in a fixation solution, labeled and sent for histological and immunohistochemical assessment. Finally, 12 dental implants were placed at treated sites for prosthetic replacement of the extracted tooth.

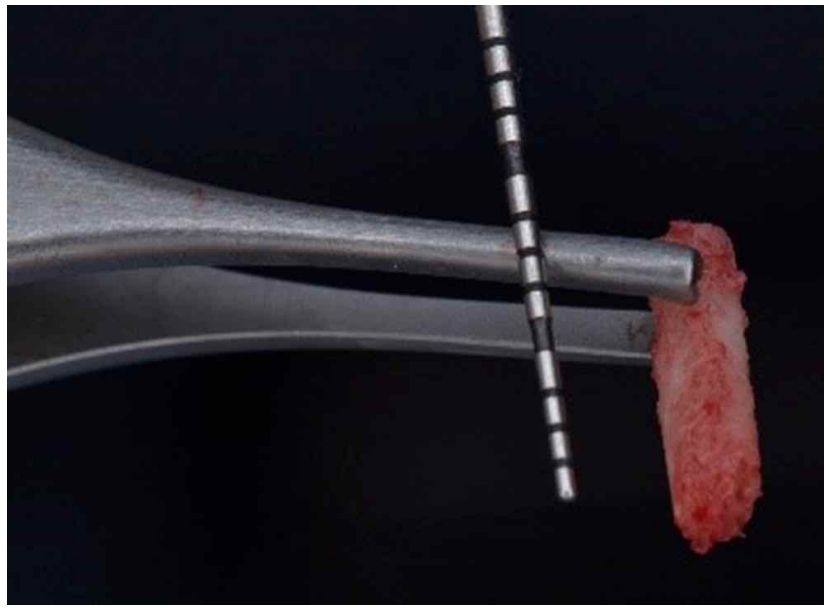

Fig. 3. Bone core incisional biopsy, $2 \times 10 \mathrm{~mm}$.

Histology and immunohistochemistry analysis. The 12 bone specimens were fixed in phosphate buffered $10 \%$ formalin for 10 days and decalcified for 24 hours with $5 \%$ hydrochloric acid and formic acid. The tissues were rinsed with distilled water, treated with buffered tissue processor, paraffin embedded, cut to thickness of $5 \mu \mathrm{m}$, deparaffinized, rehydrated in graded alcohol and stained with Hematoxylin and Eosin (H\&E). To confirm the presence of teeth particulates and osteonal bone formation in the tissue samples the histological observation was performed.

For immunohistochemistry analysis, the paraffin blocks were cut serially into $5 \mathrm{~mm}$ thick-tissue sections, on poly-L-lysine pre-coated slides. The sections were penetrated and dried overnight in an autoclave $\left(56^{\circ} \mathrm{C}\right)$, deparaffinized with xylene for 30 min, washed with 99 $\%$ alcohol for 15 min then $96 \%$ alcohol and distilled water. For OPN epitopes recovery, the sections were microwaved fourth times for $5 \mathrm{~min}$ in citrate buffer $(\mathrm{pH}$ 6.0 ), cooled to room temperature, and then washed in phosphate-buffered saline for $5 \mathrm{~min}$. Endogenous peroxidase activity was blocked with $3 \% \mathrm{H}_{2} \mathrm{O}_{2}$ in $50 \mathrm{mM}$ Tris- $\mathrm{HCl}$ for 5 minutes to prevent non-specific reactions. The tissue sections were incubated, for 120 minutes, with block solution of primary monoclonal antibodies (paratopes) against Osteopontin (1:100, Gentex. Santa Barbara, California) at a dilution of $1: 100$ and with the secondary antibodies Streptavidin-biotin. All sections were stained with the chromogen diaminobenzidine- $\mathrm{H}_{2} \mathrm{O}_{2}$ for 5 minutes. At the end of the process cell nuclei were stained with Gill's Hematoxylin. Human osseous tissue was included as a positive control, and negative control section treated with phosphate-buffered antibodies was confirmed to be unstained. All histological and immunostained specimens were observed by an oral pathologist and then images were captured using a digital camera (Canon EFS $18-55 \mathrm{~mm}$, macro 0.25/0.8ft).

Results of the histological and immuno histochemical assessment. Twelve bone tissue trephine cores were harvested from 5 patients and analyzed for: a) Residual teeth graft; b) Newly formed bone; c) Mature bone; and d) Immunoexpression pattern of OPN. 
Residual teeth graft, new formed bone and mature bone. The histological observation of the H\&E samples reveled irregular and dense connective tissue

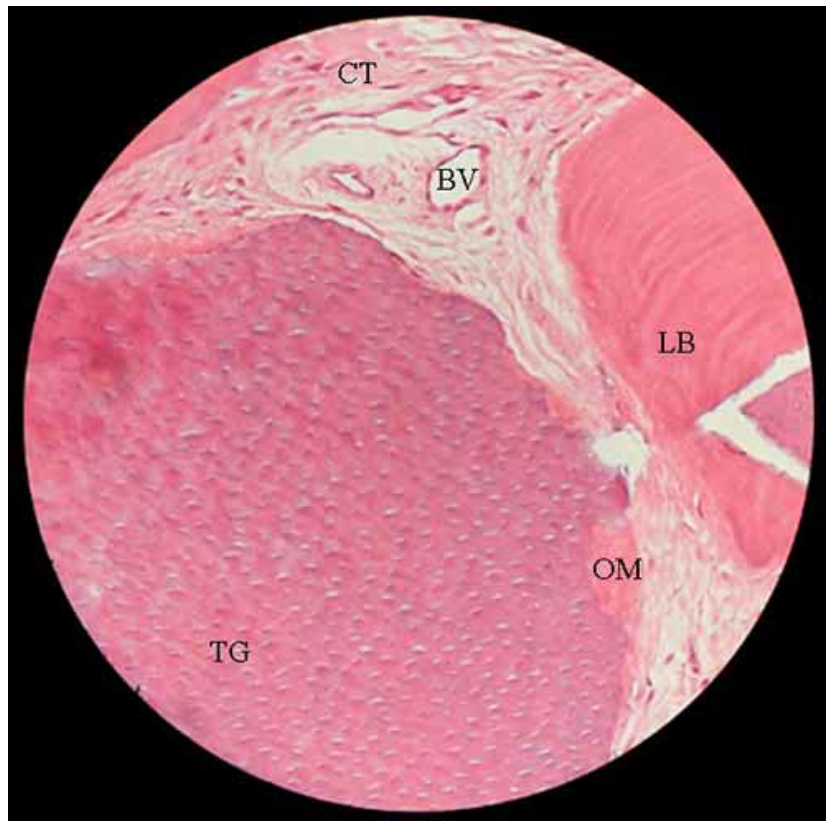

Fig. 4. Teeth graft particle (TG) in direct contact with newly deposited osteoid matrix (OM) colored in red, surrounded by a dense connective tissue (CT) colored in deep pink, and blood vessels (BV), next to mature, native, lamellar bone (LB, H\&E, X100).

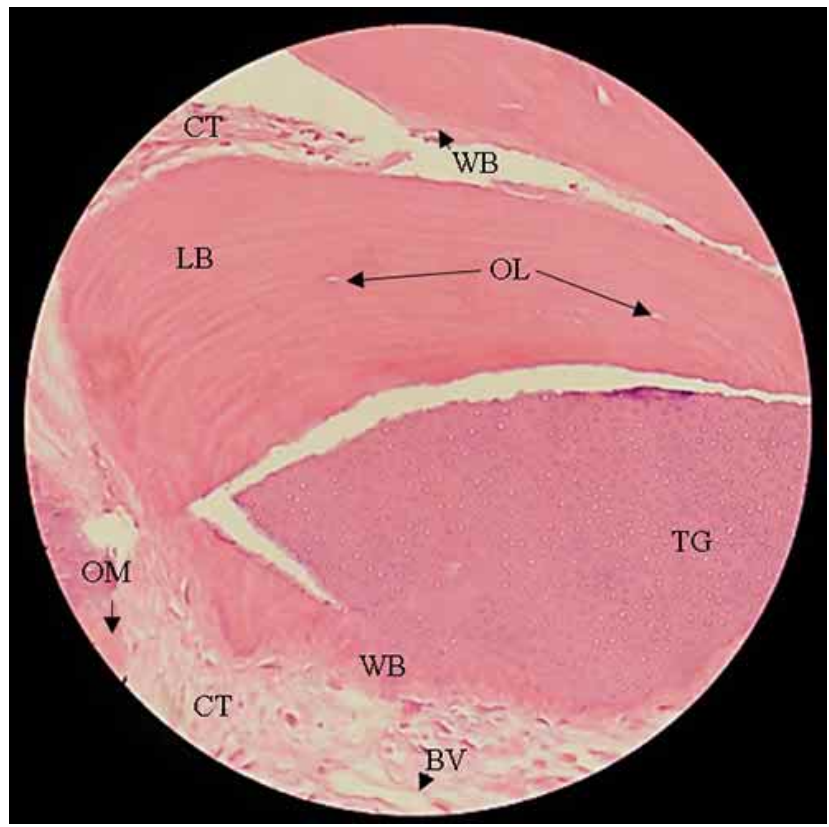

Fig. 5. Woven bone (WB) apposition over the irregular edge of the tooth graft particle (TG) in transition to mature lamellar bone (LB), surrounded by supportive connective tissue (CT) and blood vessels (BV). Osteoid matrix (OM) formed over a near dentine particle is also seen (H\&E, X100). areas formed by perivascular mesenquimal cells occupying the spaces created in the grafted sites by the extensive dissolution from the teeth graft particles (Fig. 4). Newly osteoid matrix deposition was seen in tiny areas and in direct contact with teeth graft, while a wide deposition of woven bone was observed in several of the biopsied specimens, associated with loose supportive connective tissue and abundant blood vessels (Fig. 5). Some teeth graft particles remained without being reabsorbed, showing dentinal tubules and an irregular edge. Also, areas were observed of mature native bone with a ribbon shaped apposition and in direct contact with the remaining teeth particles as well as some focal areas of peripherical woven bone suggestive of an asynchronic bone remodeling at the grafted sites (Fig. 6). No osteoblasts, leucocytes or fibroblasts were observed in all analyzed samples.

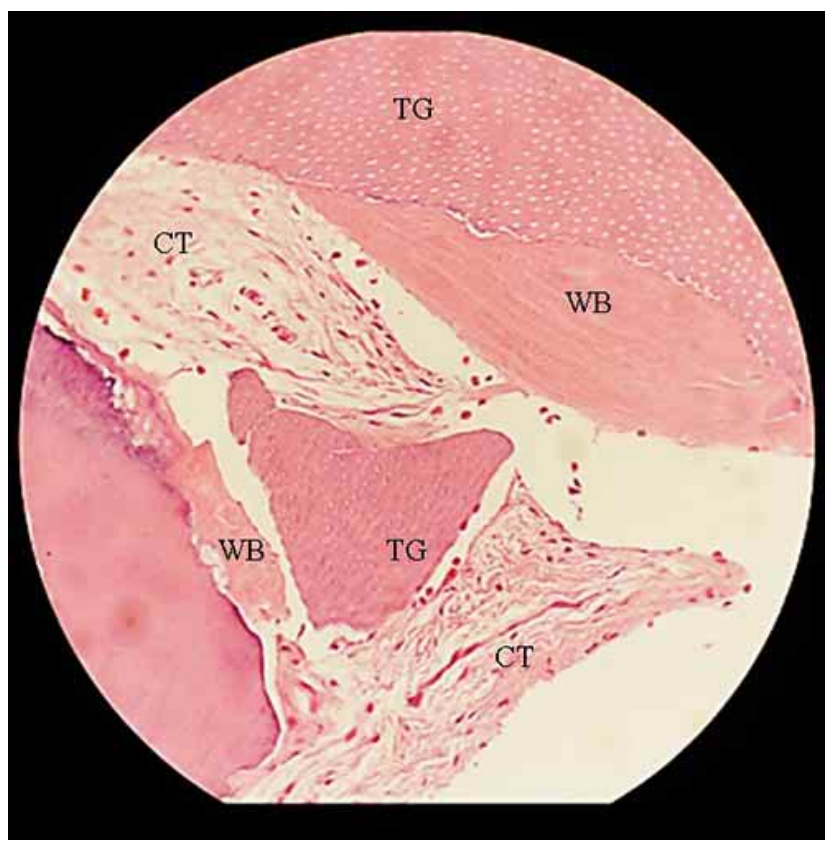

Fig. 6. New woven bone (WB) formed in direct contact with the remaining teeth graft (TG), made up of dentin. Loose connective tissue (CT) is also seen (H\&E, X100).

Immunoexpression of osteopontin (OPN). Immunohistochemistry analysis of the collected samples, after 8 months healing period, reveled a moderate OPN positive expression in $50 \%$ of the areas of interest, principally over the surfaces of new formed bone, tooth graft particles and along the peritubular spaces of dentin fragments (Figure 7). Also, the observed microscopic fields evidenced positive labeling OPN reaction at the interfaces of direct osteodental connection, mainly constituted by dentine and woven bone tissue, which showed wide medullary spaces and 


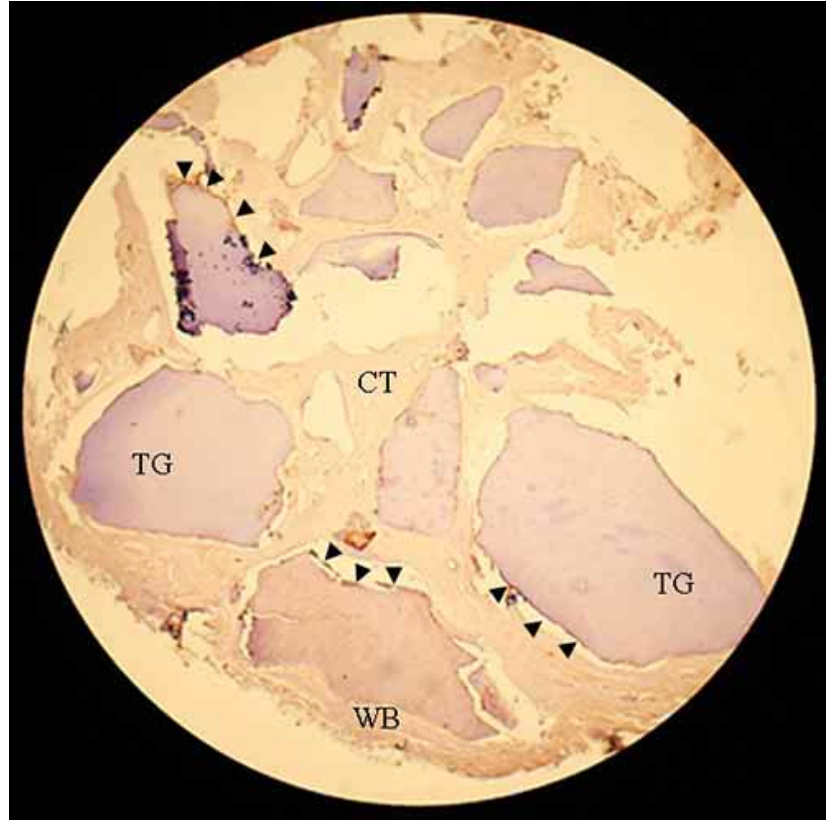

Fig. 7. OPN immunoreaction shows moderate OPN immunostaining, contrasted by a brown color (head arrows), that evidence the positive expression of the glycoprotein over the edges of the tooth graft particles (TG) that were not completely reabsorbed and presented woven bone (WB) apposition rounded by supportive connective tissue (CT, X40).

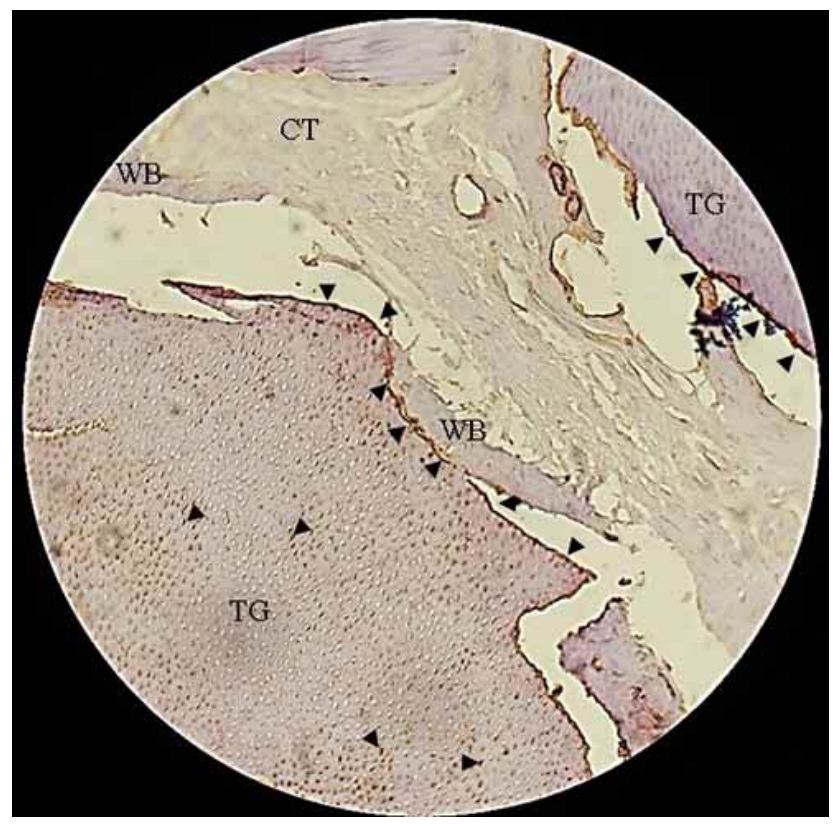

Fig. 8. OPN immunoreaction shows positive OPN brown staining (arrow heads), moderate expressed over the surface of tooth graft particle (TG), into the woven bone-dentine interface (WB-TG) and inside the peritubular spaces of the dentin. Some connective tissue is also seen forming dense collagen fibers with vascular spaces (X100). active sites of immunopositive OPN, characterized by superficial osteoid material (Figure 8). Likewise, the amount of residual dentin graft particles was irregular in all samples, this could be due to most graft underwent resorption during bone healing and remodeling. Nevertheless, not one of the observed biopsies showed evidence of osteoclast presence nor its biologic activity. In contrast, $50 \%$ of the biopsies detected the formation of mature bone in contact with the dentin graft particles, with moderate OPN immunoreaction in osteonal structures associated with the presence of welldifferentiated osteocytes (Fig. 9).

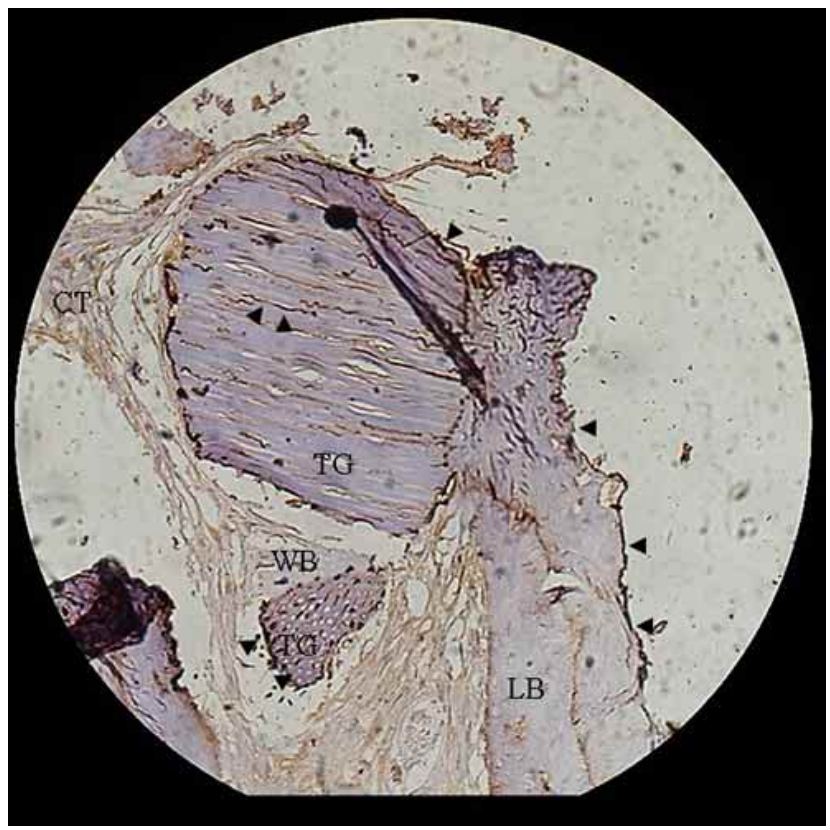

Fig. 9. Positive OPN immunoreaction revealed by a brown staining (arrow heads), distinguishable in the surface of lamellar bone (LB) that presents an osteonal structure, associated with the presence of well-differentiated osteocytes, and that is in direct contact with the dentin graft particles (TG) that also shows a woven bone apposition (WB) and a positive OPN reaction along its tubular spaces. Loose supportive connective tissue (CT) is surrounding the osteodental integration (X100).

\section{DISCUSSION}

The ideal properties of a bone regenerative biomaterial include 3 main characteristics: osteoconduction, osteoinduction and osteogenesis. Osteoconduction refers to the ability of a scaffold or implant to promote attachment, migration, growth and/ or division of osteoblastic and osteoclastic cells on the surface and throughout the interior of a scaffold or implant (Ratner et al., 2013; Wypych, 2018). Since 1965, Dr. 
Marshal Urist discovered that decalcified matrix of teeth constitute a substrate that evokes determination of mesenchymal cells into cartilage and bone cells, due to certain "conditions or transforming factors", that change its phenotype, from an undifferentiated state into terminal chondroblast or osteoblast cells (Urist, 1965). Further studies concluded that autogenous teeth bone grafts lead to hidroxiapatite (HA) mineral nucleation during alveolar bone healing, occurring because of a local ostoconductive and osteoinductive phenomena (Kim et al., 2010), since then mineralized dental tissues have been elucidated as an alternative for autologous bone grafts in alveolar bone regeneration, preservation and augmentation procedures.

A huge amount of scientific reports have showed that mineralized apatite of dental tissues spontaneously promotes bone cells activity, especially in the absence of periodontal ligament tissue (Andreasen, 1980), this is the main proof of the osteoconductive properties of the tooth graft. Recently, an animal study, conducted by Shwarz et al. (2016) documented that even tooth blocks were osteoconductive when fixed at atrophied edentulous ridges, as it was found parallel-fibred woven bone in close contact with dentin and osteodentin, after a 3 month healing period. The present study shows the histological and immunohistochemical analysis of incisional alveolar bone biopsies harvested from human alveolar ridges preserved with autogenous particulate teeth graft. The specimens analyzed in this study revealed vital bone appositioned in close contact with partially absorbed dental particles, possibly because timing of harvesting allowed the replacement of the dental graft with new bone. Particularly, remnant fragments of dentin presented rough and irregular edges, structurally attached to osteoid matrix depositions or newly formed woven bone. We hypothesize that gradual absorption of the mineralized dental particles, gave them a roughness topography that enhanced their surface area of contact, at a microscopic level, and that could promote osteoblast attachment and migration, as well as osteoid matrix synthesis and the expression of binding sites for the extracellular matrix proteins involved in bone maturation and bone turnover.

On the other hand, osteoinduction implies the ability of a biomaterial to promote the recruitment of immature cells and the stimulation of these cells to determinate into preosteoblasts (Albrektsson \& Johansson, 2001). In this study, dense formations of connective tissue were detected around some teeth particles in form of thick collagen fibers that were simi- lar to those observed during the intramembranous bone formation that occurs in the ossification of the grafted bone sites (Ross \& Pawlina, 2011), this observation might support the osteoinductive potential of autologous tooth graft, as the more dense connective tissue eventually could form the periosteum and endosteum layers that would allow the recruitment and adherence of undifferentiated perivascular mesenchymal cells and bone cell precursors. The immunohistochemical pattern expression of OPN in alveolar bone preserved with autogenous teeth graft is of special value in detecting the osteoinductive effect promoted by this fresh bone substitute at a molecular level, because previous studies have found that OPN secretion by alveolar bone osteoblast exhibit an important biofunctional role in the early stage of angiogenesis (Wein et al., 2019) and HA nucleation during the alveolar bone healing (de Bruyn et al., 2013).

Osteopontin (OPN) is an acidic, flexible, negative charged and intrinsically disordered, extracellular glycol-phosphoprotein, express by a wide variety of cell types and found in many human tissues and body fluids, including bone, skin, urine, milk and blood (Sodeck \& Mckee, 2000). OPN was first described by Senger et al., in 1979[MOU1] , as a molecule that has many important and diverse functional roles in different biological processes and systems; though it was named Osteopontin for its partition in non-collagenous bone matrix formation, when it is secreted by osteoblastic cells. During the formation of hydroxyapatite (HA, Ca10(PO4)6(OH)2), the major mineral component of human bone and teeth, phosphorylated OPN plays a modulatory role in the microenvironment of the biomineralization process. Evidence shows that, attached phosphates to OPN molecule inhibits the nucleation of HA crystal growth, because phosphate groups increase the electronegativity of OPN, resulting in a stronger interaction with cationic HA crystal faces. Consequently, the negatively charged OPN bind large amounts of positively charged calcium ions, effectively lowering the HA concentration and precipitation in the osteoid matrix, while the few particles that do nucleate, however, grow more quickly. OPN, also bind to small calcium phosphate clusters, preventing them from growing large enough to become stable, resulting in their re-dissolution, so it is until the free molecules of OPN are reduced, when the remaining calcium phosphate crystals growth faster and transform into crystalline HA (de Bruyn et al.).

The immunohistochemical analysis of this study documented a moderate detection of OPN epitopes in 
MORENO-VILLAGRANA A. P.; GUTIÉRREZ-VALDÉS, D. H. \& FLORES-LUNA, M. G. Immunohistochemical analysis of alveolar bone preserved with autologous teeth graft. Osteopontin expression and its regulatory functions in preserved alveolar ridge. Int. J. Odontostomat., 15(3):616-625, 2021.

processed bone sections, after an 8-month healing period. The OPN positive immunostaining was detected over the surface of the tooth graft particles, inside its peritubular spaces, on the surfaces of new bone formations and in the interfaces of osteodental connection. A proteomic analysis, conducted by Foster et al. in 2018, pointed that the specific forms of OPN that are produced in the dentoalveolar tissues are still unknow, as well as their phosphorylation status which is critical to the potency of OPN to regulate bone mineralization. However, some authors describe it is possible that OPN exists in a relatively dephosphorylated state to be more effective as an attachment and signaling protein (Christensen et al., 2012). The evidence of this study is limited to suggest the functional roles of the locally produced OPN during the healing and remodeling of the alveolar bone preserved with autologous teeth graft. Nevertheless, the positive detection of OPN over the surfaces of dental graft and new bone formations indicate a high affinity between locally synthetized OPN and mineralized tissues which might influence local cell conduct, including attachment, differentiation, migration and maturation.

Additional to the immunohistochemical evidence of the teeth particles as an autologous bone grafting material, there are clinical advantage that are beneficial for patient post extraction management. First, there is no need to generate additional surgical wounds to harvest the bone grafting tissue, a characteristic that is reiterated in scientific reports (Jeong et al., 2011) and that lead to a safe and non resective option to not discard hopeless teeth and its biological properties. Second, at the present time, there have been no reported adverse immunologic reaction or immunogenic complications resulting from bone or intracranial grafting techniques using autologous mineralized tooth tissues, crushed or in block form (Jeong et al.). Third, our findings show that mineralized dental tissue provides fresh alveolar sockets with a mechanical scaffold associated with a moderate local OPN expression that is related to its roughness surfaces and its peritubular dentine spaces. Finally, local tooth graft absorption promotes a HA dissolution that release calcium and phosphate ions necessary for osteoid mineralization and bone regrowth.

One drawback of this study is the lack of histological samples harvested at control sites, defined by non-grafted and spontaneously healed dental sockets, in order to compare new bone apposition and OPN pattern expression in native newly formed alveolar bone. Additionally, randomized controlled clinical trials with bone volume analysis and primary implant stabilization measures are needed for a full evaluation of the biological efficacy of autologous tooth graft in alveolar bone preservation. Also, it is important to note that this is the first quasi experimental study demonstrating OPN expression in alveolar ridge preserved with particulate autologous toot graft.

\section{CONCLUSION}

The evidence from the study shows that the autologous dental graft is a biocompatible bone substitute, that provides an osteoconductive scaffold that promotes bone cell adhesion and migration for local osteogenesis and that it is associated with moderate in situ expression of osteopontin , which showed a high affinity with mineralized dental tissue, suggesting osteoinductive properties in situ.

\section{ACKNOWLEDGEMENTS}

The authors would like to thank the students: Cynthia Rocío Barcenas García, Jennifer Miranda Ortega, Eliuth Delizabeth Ponce Rongel and Aketzalli Ruiz Meza, for their participation in the execution of the clinical procedures of this study. It is also appreciated the collaboration of the students: Luis Alfonso Rocha Peláez and Edwin Ricardo Valdés Ramírez for their participation in taking clinical photographs. Likewise, kindly appreciated are the efforts of Mr. José Eduardo Farfán Morales and Mr. Teodomiro Pérez Salazar, for their competent labor in the laboratory procedures of this study. The authors declare that they have no conflicts of interest with the contents of this manuscript and they do not receive any kind of financial supports or grants.

MORENO-VILLAGRANA A. P.; GUTIÉRREZ-VALDÉS, D. H. \& FLORES-LUNA, M. G. Análisis inmunohistoquímico de hueso alveolar preservado con injerto dental autólogo. Expresión de osteopontina y sus funciones regulatorias en el reborde alveolar preservado. Int. J. Odontostomat., 15(3):616-625, 2021.

RESUMEN: El presente estudio investigó el resultado cicatrizal de 12 alvéolos frescos postextracción injertados con dientes autólogos particulados para lograr la preservación del reborde alveolar postextracción. El objetivo 
es dilucidar las propiedades osteoconductivas y osteoinductivas del injerto dental autólogo utilizado como sustituto óseo en la técnica de preservación de reborde. Se incluyeron 5 pacientes, con al menos un diente sin esperanza y con necesidad de extracción y preservación del reborde, para recibir en el mismo sitio un implante dental en sustitución protésica. En la primera etapa quirúrgica, se realizaron las extracciones dentales y la preservación del reborde alveolar, utilizando como sustituto óseo los dientes extraídos y procesados con un sistema automático. En la segunda etapa quirúrgica, se realizó una biopsia ósea incisional en cada sitio injertado, los lechos óseos fueron recapitulados en un protocolo de fresado que permitió la colocación del implante dental y los especímenes óseos recolectados fueron preparados para su análisis. Los resultados histológicos de las biopsias óseas en todos los casos mostraron partículas remanentes del injerto dental, conformadas por dentina, parcialmente reabsorbidas, con margenes superficiales irregulares y en estrecho contacto con depósitos de hueso de reciente formación en transición hacia hueso laminar maduro, en el cual se observaron osteocitos bien diferenciados. Los resultados inmunohistoquímicos mostraron una expresión positiva moderada de osteopontina en los bordes de las partículas del injerto dental integrado, al interior del espacio peritubular dentinario y en las interfases de contacto osteodental. En conclusión, la evidencia del estudio muestra que el injerto dental autólogo es un sustituto óseo biocompatible, que provee un andamio osteoconductivo promotor de la adhesión y migración de las células óseas para la osteogénesis local y que está asociado a la expresión modera in situ de osteopontina, la cual mostro una alta afinidad con el tejido dental mineralizado, sugiriendo propiedades osteoinductivas in situ.

\section{PALABRAS CLAVE: injerto dental, injerto óseo alveolar, preservación de reborde alveolar, osteopontina.}

\section{REFERENCES}

Al-Asfour, A.; Farzad, P.; Andersson, L.; Joseph, B. \& Dahlin C. Host tissue reactions of non-demineralized autogenic and xenogenic dentin blocks implanted in a non-osteogenic environment. An experimental study in rabbits. Dent. Traumatol., 30(3):198-203, 2014.

Albrektsson, T. \& Johansson, C. Osteoinduction, osteoconduction and osseointegration. Eur. Spine J., 10(Supp/ 2):S96-S101, 2001.

Andersson, L.; Blomlöf, L.; Lindskog, S.; Feiglin, B. \& Hammarström, L. Tooth ankylosis. Clinical, radiographic and histological assessments. Int. J. Oral Surg., 13(5):423-31, 1984.

Andreasen $\mathrm{O}$. Analysis of pathogenesis and topography of replacement root resorption (ankylosis) after replantation of mature permanent incisors in monkeys. Swed. Dent. J., 4(6):23140, 1980.

Araújo, M. G. \& Lindhe, J. Dimensional ridge alterations following tooth extraction. An experimental study in the dog. J. Clin. Periodontol., 32(2):212-8, 2005.
Araújo, M. G.; Silva, C. O.; Misawa, M. \& Sukekava, F. Alveolar socket healing: what can we learn? Periodontol. 2000, 68(1):12234, 2015.

Atwood, D. A. Reduction of residual ridges: A major oral disease entity. J. Prosthet. Dent. 26(3):266-79, 1971.

Buser, D.; Warren, K. \& Karring, T. Formation of a periodontal ligament around titanium implants. J. Periodontol., 61(9):597601, 1990

Chan, H. L.; Lin, G. H.; Fu, J. H. \& Wang, H. L. Alterations in bone quality after socket preservation with grafting materials: a systematic review. Int. J. Oral Maxillofac. Implants., 28(3):71020, 2013

Christensen, B.; Kläning, E.; Nielsen, M. S.; Andersen, M. H. \& Sørensen, E. S. C-terminal modification of osteopontin inhibits interaction with the aVb3-integrin. J. Biol. Chem., 287(6):378897, 2012.

de Bruyn, J. R.; Goiko, M.; Mozzaffari, M.; Bator, D.; Dauphinee, R. L.; Liao, Y.; Flemming, R. L.; Bramble, M. S.; Hunter, G. K. \& Goldberg, H. A. Dynamic light scattering study of inhibition of nucleation and growth of hydroxyapatite crystals by osteopontin. Plos One, 8(2):e56764, 2013.

Foster, B. L.; Ao, M.; Salmon, C. R.; Chavez, M. B.; Kolli, T. N.; Tran, A. B.; Chu, E. Y.; Kantovitz, K. R.; Yadav, M.; Narisawa, S.; Millán, J. L.; Nociti, F. H. Jr. \& Somerman, M. J. Osteopontin regulates dentin and alveolar bone development and mineralization. Bone, 107:196-207, 2018.

Giachelli, C. M. Inducers and inhibitors of biomineralization: lessons from pathological calcification. Orthod. Craniofac. Res., 8(4):22937, 2005.

Horowitz, R.; Holtzclaw, D. \& Rosen, P. S. A review on alveolar ridge preseration following tooth extraction. J. Evid. Based Dent. Pract., 12(Supp/ 3):149-60, 2012.

Huggins, C.; Wiseman, S. \& Reddi, A. H. Transformation of fibroblasts by allogeneic and xenogeneic transplants of demineralized tooth and bone. J. Exp. Med., 132(6):1250-8, 1970.

Jeong, K. I.; Kim, S. G.; Kim, Y. K.; Oh, J. S.; Jeong, M. A. \& Park, J. J. Clinical study of graft materials using autogenous teeth in maxillary sinus augmentation. Implant Dent., 20(6):471-5, 2011.

Kadkhodazadeh, M.; Ghasemianpour, M.; Soltanian, N.; Sultanian, G. R.; Ahmadpour, S. \& Amid, R. Effects of fresh mineraized dentin and cementum on socket healing a preliminary study in dogs. $J$. Korean Assoc. Oral Maxillofac. Surg., 41(3):119-23, 2015.

Kim, Y. K.; Kim, S. G.; Byeon, J. H.; Lee, H. J.; Um, I. U.; Lim, S. C. \& Kim, S. Y. Development of a novel bone grafting material using autogenous teeth. Oral Surg. Oral Med. Oral Pathol. Oral Radiol. Endod., 109(4):496-503, 2010.

Kim, Y. K.; Kim, S. G.; Yun, P. Y.; Yeo, I. S.; Jin, S. C.; Oh, J. S.; Kim, H. J.; Yu, S. K.; Lee, S. Y.; Kim, J. S.; Um, I. W.; Jeong, M. A. \& Kim, G. W. Autogenous teeth used for bone grafting: a comparison with traditional grafting materials. Oral Surg. Oral Med. Oral Pathol. Oral Radiol., 117(1):e39-e45, 2014a.

Kim, Y. K.; Yun, P. Y.; Um, I. W.; Lee, H. J.; Yi, Y. J.; Bae, J. H. \& Lee, J. Alveolar ridge preservation of an extraction socket using autogenous tooth bone graft material for implant site development: prospective case series. J. Adv. Prosthodont., 6(1):521-7, 2014b.

Pietrokovski, J. \& Massler, M. Alveolar ridge resorption following tooth extraction. J. Prosthet. Dent., 17(1):21-7, 1967.

Pindborg, J. J. Pathology of the dental hard tissues. Saunders, Philadelphia, 1970.

Ratner, B. D.; Hoffman, A. S.; Schoen, F. J. \& Lemons, J. E. Biomaterials science. An Introduction to Materials in Medicine. 3rd ed. Elsevier Academic Press, Massachusetts, 2013.

Ross, M. H. \& Pawlina, W. Histology. A text atlas with correlated cell and molecular biology. 6th ed. Lippincott Williams \& Wilkins, Maryland, 2011. 
MORENO-VILLAGRANA A. P.; GUTIÉRREZ-VALDÉS, D. H. \& FLORES-LUNA, M. G. Immunohistochemical analysis of alveolar bone preserved with autologous teeth graft. Osteopontin expression and its regulatory functions in preserved alveolar ridge. Int. J. Odontostomat., 15(3):616-625, 2021.

Salmon, C. R.; Giorgetti, A.; Paes Leme, A. F.; Domingues, R. R.; Kolli, T. N.; Foster, B. L. \& Nociti, F. H. Jr. Microproteome of dentoalveolar tissues. Bone, 101:219-29, 2017.

Senger, D. R.; Ledbetter, S. R.; Claffey, K. P.; Papadopoulos-Sergiou, A. \& Peruzzi, C. A. Detmar M. Stimulation of endothelial cell migration by vascular permeability factor / vascular endothelial growth factor through cooperative mechanisms involving the aVb3 integrin, osteopontin, and thrombin. Am. J. Pathol., 149(1):293-305, 1996.

Shwarz, F.; Golubovic, V.; Becker, K. \& Mihatovic, I. Extracted tooth roots used for lateral alveolar ridge augmentation: a proof-ofconcept study. J. Clin. Periodontol., 43(4):345-53, 2016.

Sodeck, J. \& Mckee, F. D. Molecular and cellular biology of alveolar bone. Periodontol. 2000, 24:99-126, 2000.

Upadhyay, P.; Blaggana, V.; Tripathi, P. \& Jindal M. Treatment of furcation involvement using autologous tooth graft with 1-year follw-up: a case series. Clin. Adv. Periodontics, 9(1):1-8, 2019.

Urist, M. R. Bone: formation by autoinduction. Science, 150(3698):893-9, 1965.

Wein, M.; Huelter-Hassler, D.; Nelson, K.; Fretwurst, T.; Nahles, S.; Finkenzeller, G.; Altmann, B. \& Steinberg, T. Differential osteopontin expression in human osteoblasts derived from iliac crest and alveolar bone and its role in early stages of angiogenesis. J. Bone Miner. Metab., 37(1):105-17, 2019.

Willenbacher, M.; Al-Nawas, B.; Berres, M.; Kämmerer, P. W. \& Schiegnitz, E. The effects of alveolar ridge preservation: a metaanalysis. Clin. Implant. Dent. Relat. Res., 18(6):1248-68, 2016.

Wypych, G. Functional fillers. Chemical composition, morphology, performance, applications. ChemTec Publishing, Toronto, 2018.

Yeomans, J. D. \& Urist, M. R. Bone induction by decalcified dentine implanted into oral, osseous and muscle tissues. Arch. Oral Biol., 12(8):999-1008, 1967.
Corresponding author:

Ana Patricia Moreno Villagrana.

Professor at Universidad Tecnológica de México (UNITEC)

Faculty of Dentistry

Postgraduate Division

Periodontics Department

MEXICO

E-mail: ana_morenov@my.unitec.edu.mx 